\title{
Retinopathy in patients with hypertension and/ or diabetes in a family health unit
}

\author{
Retinopatia em pacientes hipertensos e/ou diabéticos \\ em uma unidade de saúde da família
}

Aline Pinto Alves ${ }^{1}$, Reny Wane Vieira dos Santos ${ }^{1}$, Edmundo Frota de Almeida Sobrinho ${ }^{2}$, Sheila Patrícia Lopes Rocha ${ }^{1}$, Ana Cláudia Nóbrega Loch $^{3}$

\begin{abstract}
Purpose: To identify the prevalence of abnormal ophthalmoscopy in patients with systemic hypertension (SH) and / or diabetes mellitus $(D M)$ in a Family Health Unit (FHU). Method: was performed a individual study, observational, primarily descriptive and crosssectional of a sample of a cohort of 50 patients with hypertension and / or diabetic enrolled in the program HIPERDIA in a FHU of the city of Ananindeua - Para, between the months of september and november 2009. Results: ophthalmoscopy was performed in 46 patients and $27(58.7 \%)$ had some alteration. When performing a specific analysis (excluding the findings of arteriolar narrowing and venous engorgement) were changes in 18 (39.1\%), 45.5\% with DM and SH, 40\% with DM and 36\% with SH. Conclusion: The high prevalence of the changes in ophthalmoscopy found in this study demonstrates that effectiveness as a screening method in the context of primary health care, justifying that use. corroborates also the importance of primary care in the prevention of diabetic and hypertensive retinopathy, through periodic control of patients at high vascular risk as the population studied.
\end{abstract}

Keywords: Prevention; Diabetic retinopathy; Hypertensive retinopathy; Diabetes mellitus; Hypertension

\section{Resumo}

Objetivo: Identificar a prevalência de alterações à oftalmoscopia direta em pacientes com diagnóstico de hipertensão e/ou diabetes mellitus em uma Unidade de Saúde da Família (USF). Método: Estudo individual, observacional, prioritariamente descritivo, do tipo transversal, com amostra composta por coorte de 50 pacientes hipertensos e/ou diabéticos matriculados no programa HIPERDIA de uma Unidade de Saúde Familiar (USF) do município de Ananindeua - Pará, entre os meses de setembro e novembro de 2009. Resultados: Foi realizada oftalmoscopia em 46 pacientes. Observou-se alteração à oftalmoscopia em 27 (58,7\%). Ao realizar a análise específica (excluindo-se os achados de estreitamento arteriolar e ingurgitamento venoso) houve alterações em 18 (39,1\%), sendo 45,5\% com DM e HAS, quarenta por cento com DM e 36\% com HAS. Conclusão: A elevada prevalência de alterações à oftalmoscopia encontradas no presente estudo demonstra sua eficácia como método de rastreio no contexto da atenção primária a saúde, justificando seu uso. Corrobora, ainda, a importância da atenção primária à saúde na prevenção da retinopatia hipertensiva e diabética, através do controle periódico de pacientes de alto risco vascular como a população estudada. Descritores: Prevenção; Retinopatia diabética; Retinopatia hipertensiva; Diabetes mellitus; Hipertensão

\footnotetext{
${ }^{1}$ M.D., Medical and Surgical School of Pará, Federal University of Pará (UFPA), Belém/PA, Brazil.

2 Ph.D. in Ophthalmology, Ophthalmic Clinic of the Federal University of Minas Gerais (UFMG). Professor of Ophthalmology, Medical and Surgical School of Pará, Federal University of Pará (UFPA), Belém/PA, Brazil.

${ }^{3}$ M.D., Medical School of the Federal University of Amazonas (UFAM), Manaus/AM, Brazil.
}

Federal University of Pará, Medical and Surgical School of Pará, University Hospital Bettina Ferro de Souza, Department of Ophthalmology, Belém/PA, Brazil.

\footnotetext{
*This study is part of the programme "Direct monocular ophthalmoscopy in patients with hypertension and/or diabetes in a family health unit", which received two research grants offered by PIBEX.
}

\section{The authors declare no conflict of interest.}




\section{INTRODUCTION}

H ypertension and diabetes mellitus (DM) are the major risk factors for cardiovascular disease and have been the leading cause of death in Brazil in recent decades ${ }^{(1,2)}$. These are chronic conditions that result in high costs with hospitalisations and complex procedures for the treatment of long-term complications ${ }^{(3)}$.

Diabetic retinopathy (DR) is one of the microvascular complications of diabetes, particularly in long-term diabetes with poor glycemic control. It is estimated that $99 \%$ of patients with type $1 \mathrm{DM}$ and $60 \%$ of patients with type $2 \mathrm{DM}$ suffer from some type of DR after 20 years with the disease, making it the main cause of acquired blindness in adults ${ }^{(4-6)}$.

Hypertensive retinopathy (HR) is characterised as a spectrum of vascular changes in the retina of individuals with high blood pressure. Screening patients for the condition is critical as it is an indication for drug therapy, even in patients with stage 1 hypertension, because of its association with increased cardiovascular $\operatorname{risk}^{(7)}$.

The Brazilian Ministry of Health has implemented the Reorganisation Plan for Hypertension and Diabetes Mellitus Care as a strategy to reorganise primary care. The programme involves collecting data on these patients in a national database called HIPERDIA $^{(1)}$. Therefore, primary-care physicians are essential to minimise the long-term complications of these conditions. Training physicians and providing ophthalmoscopes to family health clinics would increase the number of patients referred to timely specialised care, allowing early diagnosis of retinopathy and better treatment outcomes.

\section{Methods}

Individual, observational, primarily descriptive crosssectional study. The study sample was a cohort of 50 patients with hypertension and/or diabetes seen at a Family Health Unit (FHU) in the municipality of Ananindeua, Pará, and included in the HIPERDIA database. Patients who sought the FHU for medical or nursing consultations between September and November 2009 were included in the study through nonprobabilistic convenience sampling.
Data collection was done weekly in the FHU through a questionnaire applied in a private room, measurement of blood pressure, and ophthalmoscopy with pupillary dilation by tropicamide and phenylephrine.

Patients with significant changes on fundus examination were referred for ophthalmic evaluation at the University Hospital Bettina Ferro de Souza (HUBFS), where they underwent retinography and specific treatment where appropriate.

Qualitative and quantitative statistical analysis was done using the EpiInfo 3.5.1 software. Uni- and bivariate analysis was conducted using the chi-square test with Yates correction, where applicable, and Fisher's exact test, with a significance level of $5 \%$ and a $95 \%$ confidence interval $(95 \% \mathrm{CI})$.

Statistical analysis of ophthalmoscopic changes was done in two stages: one in which all changes were considered (where $\mathrm{p}=\mathrm{p}_{1}$ ), and another excluding the findings of arteriolar narrowing or mild vein engorgement (specific analysis where $p=p_{2}$ ), as these findings can also be related to other factors such as old age and arteriosclerotic retinopathy.

\section{Results}

Most study subjects were female $(68 \%)\left(\mathrm{p}_{1}=0.03, \mathrm{p}_{2}=\right.$ 0.0002 ). Mean age was $62 \pm 11.73$ years (Table 1 ).

Among the interviewed patients $28(56 \%)$ had hypertension only, $10(20 \%)$ had DM only, and $12(24 \%)$ had both diseases. On average, patients had had hypertension for $10.07 \pm 6.61$ years and DM for $9.63 \pm 7.87$ years. The last reported fasting plasma glucose was $164.32 \pm 111.04 \mathrm{mg} / \mathrm{dl}$ (Limits: 71-491) on average. Mean systolic blood pressure (SBP) was $142 \pm 21.76$ mmHg (Limits: $\left.110-202 ; p_{1}=0.06\right)$. Mean diastolic blood pressure (DBP) was $82 \pm 12.77 \mathrm{mmHg}$ (Limits: $60-130 ; \mathrm{p}_{2}=0.009$ ). It was found that $64 \%$ of patients were on some type of diet $\left(\mathrm{p}_{2}=0.009\right)$.

On average, patients attended $6\left( \pm 4.36, \mathrm{p}_{1}=0.03, \mathrm{p}_{2}=0.0002\right)$ medical visits per year. The last visit to an ophthalmologist had taken place on average $2.44 \pm 2.38$ years earlier (limits: 1 - 11 ; $\left.\mathrm{p}_{1}=0.03, \mathrm{p}_{2}=0.04\right)$. Seven $(14 \%)$ patients had never visited an ophthalmologist.

Ophthalmoscopy was performed in 46 subjects, and changes were found in 27 (58.7\%; 95\% CI: $43.2 \%-73.0 \%)$. The specific analysis showed changes in 18 (39.1\%; $95 \%$ CI: $25.1 \%-54.6 \%)$ subjects, of which $45.5 \%$ had DM and hypertension, $40 \%$ had DM, and 36\% had hypertension (Table 2) (Figure 1).

Table 1

Sociodemographic profile of patients included in the HIPERDIA* database in the Family Health Clinic of Ananindeua from September to November 2009

\begin{tabular}{lllc}
\hline Sociodemographic profile & & $\mathbf{N}$ & $\mathbf{\% ( N : ~ 5 0 )}$ \\
\hline Gender & Female & 34 & 68 \\
Age (mean) & 62 years & & \\
Marital status & Stable relationship & 31 & 62 \\
Schooling & Primary education & 20 & 40 \\
& Secondary education & 12 & 24 \\
Monthly income (mean) & 2,55 simes the Brazilian & & \\
minimum wage & & & \\
Persons per household (mean) & 4 & & \\
\hline
\end{tabular}

*HIPERDIA: patients with a diagnosis of hypertension and/or diabetes mellitus Source: Study protocol 
Table 2

\section{Changes on monocular direct ophthalmoscopy found in patients included in the HIPERDIA* database in the Family Health Clinic of Ananindeua from September to November 2009.}

\begin{tabular}{lcc}
\hline Ophtalmoscopic findings & N & \% \\
\hline Diffuse or focal arteriolar narrowing & 15 & 33,3 \\
Tortuous/dilated veins & 11 & 24,4 \\
Abnormal arteriovenous crossings & 6 & 13,3 \\
Microaneurysm & 6 & 13,3 \\
Hard exudate & 6 & 13,3 \\
Micro-haemorrhage & 3 & 6,7 \\
Exsudato algodonoso & 3 & 6,7 \\
Cotton wool spots & 2 & 4,4 \\
Macular oedema & 2 & 4,4 \\
Copper wire arterioles & 1 & 2,2 \\
Silver wire arterioles & 1 & 2,2 \\
\hline
\end{tabular}

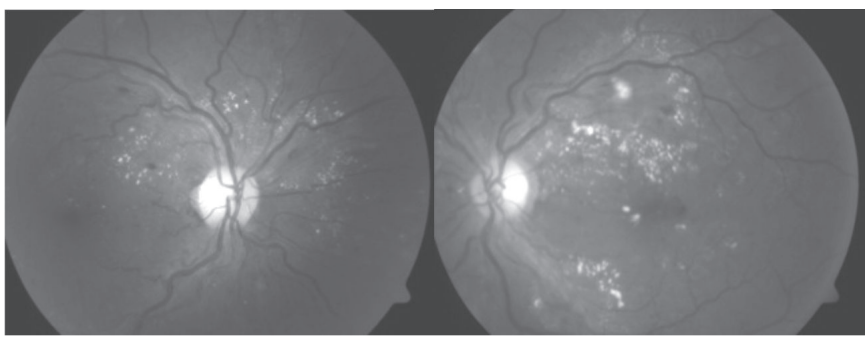

Figure 1: Retinography of a 53-year-old woman with diabetes mellitus. Diagnosis: pre-proliferative diabetic retinopathy in the left eye and non-proliferative retinopathy in the right eye.

\section{DISCUSSION}

The study population was similar to previous studies in the literature, with a predominance of females ${ }^{(8-10)}$. It is worth noting the association between female patients and changes on fundus examination, which could mean that women have a higher chance of receiving a diagnose because they seek medical care more often.

On average, patients attended $6( \pm 4.36)$ medical visits per year, which was significantly associated with changes on ophthalmoscopy $\left(\mathrm{p}_{1}=0.03, \mathrm{p}_{2}=0.0002\right)$. This result might indicate that individuals who attend medical visits less frequently may have higher chances of developing retinopathy.

This study showed that patients were not undergoing regular preventive ophthalmic care, as they had attended their last ophthalmic visit on average $2.44 \pm 2.38$ years $\left(\mathrm{p}_{1}=0.03, \mathrm{p}_{2}=0.04\right)$ earlier, and $14 \%$ reported that they had never visited an ophthalmologist, which is consistent with the literature ${ }^{(11)}$.

The average last reported fasting plasma glucose was high $(164.32 \pm 111.04 \mathrm{mg} / \mathrm{dl})$, with values as high as $491 \mathrm{mg} / \mathrm{dl}$, also similar to results found in the literature ${ }^{(10,11)}$.

Mean SBP was $142 \pm 21.76 \mathrm{mmHg}$ and mean DBP was $82 \pm 12.77 \mathrm{mmHg}$. A DBP above $90 \mathrm{mmHg}$ was significantly associated with changes on fundus examination $\left(\mathrm{p}_{2}=0.009\right)$. Chronic vascular damage caused by high blood pressure is known to be one of the main systemic complications of long-term hypertension and is often complicated by concomitant $\operatorname{DM}^{(7,10,13,14)}$
Chronic diseases such as hypertension and DM require continuous patient motivation to ensure adherence to treatment. This is why a multidisciplinary approach is essential for adequate metabolic control in order to prevent chronic complications ${ }^{(7,13)}$. In total, $64 \%$ of patients reported that they were on some type of diet, and failing to follow a diet was significantly associated with changes on fundus examination $\left(\mathrm{p}_{2}=0.009\right)$.

The prevalence of abnormal findings on fundus examination was $58.7 \%$ when all changes were considered and $39.1 \%$ when arteriolar narrowing or mild venous engorgement were excluded, demonstrating the importance of early screening of retinal changes in a population under high risk for cardiovascular disease such as the one studied here. The presence of specific findings on fundus examination was more frequent among patients with both DM and hypertension $(45.5 \%)$, which might indicate the synergistic action of the two conditions in damaging the retina ${ }^{(15,16)}$.

General practitioners and endocrinologists should be well informed about the diagnosis and treatment of retinopathy due to its significant social and economic impact. However, in a study ${ }^{(17)}$ where physicians were asked about the correct indications for ophthalmoscopy, it was correctly indicated to $86.9 \%$ of patients with type $2 \mathrm{DM}$ and only $36.9 \%$ of patients with type $1 \mathrm{DM}(\mathrm{p}<0.001)$, especially among physicians who had graduated less than 5 years earlier $(\mathrm{p}<0.003)$. The study also showed that most respondents $(52.4 \%)$ had had some experience with fundus examination during their medical studies, but only $24 \%$ actually performed it on their patients.

Another study ${ }^{(18)}$ that compared the agreement between trained family physicians and ophthalmologists in their diagnoses made by retinography suggests that, after receiving training, family physicians would be able to assess retinographies, thus confirming their important role in the integral health of patients and consolidating the importance of fundus examination as a diagnostic method in primary care. Similar results can be found in the literature ${ }^{(19,20)}$.

\section{ConCLuSION}

The high prevalence of ophthalmoscopic changes found in this study indicates the importance of primary care in the prevention of hypertensive and diabetic retinopathy. Prevention should be based in the active search for new cases, proper use of available tools such as the HIPERDIA database to plan health surveillance, and multidisciplinary management of patients aimed at strict metabolic control to avoid micro- and macrovascular complications.

Monocular direct ophthalmoscopy is a relatively simple, low-cost, and therefore accessible test that can be offered to the most deprived populations. It is an important screening and monitoring tool for patients with hypertension or diabetes, giving general practitioners more control over the clinical course of their patients and, crucially, leading to more accurate referrals of patients to ophthalmologists. This policy results in lower costs for the healthcare system as well as improved patient assessment and treatment, with better long-term outcomes and a lower disease burden. However, measures to implement ophthalmoscopy as a routine test in outpatient clinics are still incipient and do not meet population demands. 


\section{ReFERENCES}

1. Brasil. Ministério da Saúde. HIPERDIA - Sistema de Cadastramento e Acompanhamento de Hipertensos e Diabéticos. Apresentação. [citado 2009 Jan 14]. Disponível em http://hiperdia.datasus.gov.br/.

2. Ministério da Saúde. Secretaria de Políticas Públicas. Plano de Reorganização da Atenção à Hipertensão Arterial e ao Diabetes Mellitus. Rev Saúde Pública. 2001;35(6):585-8.

3. Brasil. Ministério da Saúde. Brasília: Ministério da Saúde; 2006. (Cadernos de Atenção Básica, n. 16) (Série A. Normas e Manuais Técnicos)

4. Bosco A, Lerário AC, Soriano D, Santos RF, Massote P, Galvão D, et al. Retinopatia diabética - Revisão. Arq Bras Endocrinol Metab. 2005;49(2):217-27.

5. Brasil. Ministério da Saúde. Portal da Saúde. Retinopatia Diabética. Disponível em http://portal.saude.gov.br/portal/sas/mac/ visualizar_texto.cfm?idtxt=23434\&janela=1. Acesso em 19 Jan 2009.

6. Conselho Brasileiro de Oftalmologia. Campanhas Sociais. Campanha de Retinopatia Diabética. [citado 2009 Jan 14]. Disponível em http:// www.cbo.com.br/novo/medicos/campanhas/retinopatia-diabetica

7. Brasil. Ministério da Saúde. Secretaria de Atenção à Saúde. Departamento de Atenção Básica. Hipertensão arterial sistêmica para o Sistema Único de Saúde. Brasília; Ministério da Saúde; 2006. (Cadernos de Atenção Básica, n. 16) (Série A. Normas e Manuais Técnicos)

8. Guedes MF, Portes AJ, Couto Júnior AS, Nunes JS, Oliveira RC. Prevalência da retinopatia diabética em unidade do Programa de Saúde da Família. Rev Bras Oftalmol. 2009;68(2):90-5.

9. Escarião PH, Arantes TE, Figueiroa Filho NC, Urtiga RD, Florêncio TL, Arcoverde AL. Epidemiologia e diferenças regionais da retinopatia diabética em Pernambuco, Brasil. Arq Bras Oftalmol. 2008;71(2):172-5
10. Araujo JC, Guimaraes AC. Controle da hipertensão arterial em uma unidade de saúde da família. Rev Saúde Pública, 2007;41(3):368-74

11. Ferris FL 3rd, Davis MD, Aiello LM. Treatment of diabetic retinopathy. N Engl J Med. 1999;341(9):667-78.

12. Scheffel RS, Bortolanza D, Weber CS, Costa LA, Canani LH, Santos KG, et al. Prevalência de complicações micro e macrovasculares e de seus fatores de risco em pacientes com diabetes melito do tipo $2 \mathrm{em}$ atendimento ambulatorial. Rev Assoc Med Bras. 2004;50(3):263-7.

13. Sakata K, Sakata V, Barreto Júnior J, Bottós KM, Bottós JM, Duarte Filho NP, et al. Hipertensão e retinopatia hipertensiva. Arq Bras Oftalmol. 2002;65(2):207-11.

14. Boelter MC, Azevedo MJ, Gross JL, Lavinsky J. Fatores de risco para retinopatia diabética. Arq Bras Oftalmol. 2003;66(2):239-47.

15. Illas LO, Rizo WM, Barada DL. Factores de riesgo asociados a la retinopatía diabética en pacientes diabéticos tipo II. Rev Cubana Med Gen Integr. 2006;22(1).

16. Silva VB,Temporini ER, Moreira Filho DC, Kara-José N. Tratamento da retinopatia diabética: percepções de pacientes em Rio Claro (SP) - Brasil. Arq Bras Oftalmol. 2005;68(3):363-8.

17. Preti RC, Saraiva F, Junior JA, Takahashi WY, da Silva ME. How much information do medical practitioners and endocrinologists have about diabetic retinopathy? Clinics (Sao Paulo). 2007;62(3):273-8.

\section{Corresponding author:}

Aline Pinto Alves

Rua Nova República, número 9B

CEP: 67130-740 - Cidade Nova, Ananindeua, Pará, Brazil

Telephone: +559181525775/ +559132450884

E-mail: alves.alinep@gmail.com 